\title{
1. The disnature of the firm: how did we end up here?
}

\section{THE INVENTION OF ECONOMICS}

In the beginning European Christianity's seeds of self-scrutiny and individual liberty blossomed into the Enlightenment. ${ }^{1}$ The spirit of inquiry hovered over the waters, and thinkers from all walks of life sat at a table overflowing with different theories and methodologies. Sadly, such an idyllic state of intellectual inquiry was not meant to last. And it was mainly because some decided, as did the devil in Milton's Paradise Lost, that it was preferable to reign in hell than to serve in heaven. Enter Adam Smith.

Adam Smith's name is reverentially used to support political programs and he is perceived as an economist of a particular ideology - facts which surely make him turn in his grave because (a) he had moral reservations about the free market running amok and, above all, (b) he was a moral philosopher well versed in jurisprudence, rhetoric, languages, religion, literature, and history. ${ }^{2}$ That said, he also lived in convulsive times and his thoughts were (at least partially) occupied by immediate matters such as the contemporary grain laws, both in England and France. ${ }^{3}$ Moreover, his normative thinking occurred against the backdrop of fierce infighting between George III and the aristocracy of the time, the former strengthened by the downfall of the Jacobite cause

1 David A. Hollinger, 'The Accommodation of Protestant Christianity with the Enlightenment: An Old Drama Still Being Enacted' Dædalus, the Journal of the American Academy of Arts and Sciences [Winter 2012] 141(1): 11; William Bristow, 'Enlightenment' in Edward N. Zalta (ed.), The Stanford Encyclopedia of Philosophy (2011) <https://plato.stanford.edu/archives/sum 2011/entries/enlightenment/> accessed 17 April 2017.

2 Charles L. Griswold Jr, Adam Smith and the Virtues of Enlightenment (Cambridge University Press 1999) 8-10.

3 I. Hont and M. Ignatieff, Wealth and Virtue: The Shaping of Political Economy in the Scottish Enlightenment (Cambridge University Press 1983) 15-19. 
and the latter emboldened by Gustav III's 1772 coup. ${ }^{4}$ What is most striking about Smith, however, is that, in many respects, the gulf between his eclectic approach to thinking and the current state of economics could not be wider. To begin with, and unlike, say, Ricardo, the Scotsman used both the inductive and the deductive methods, demonstrating the richness of his liberal education; second, he did not frown upon using history in his writings, something which was relegated to a different discipline after the marginalist revolution; and, third, at least in his Theory of Moral Sentiments, his homo economicus is not a Benthamite single-minded and selfish utility maximizer through and through but an agent forming part of a wider social context. ${ }^{5}$ Perhaps if Smith had remained steadfast in his Enlightenment ideals ${ }^{6}$ history would be a bit different now.

Ironically, from the three grand ideas plucked from Smith's garden for the sake of posterity - the invisible hand, the division of labor, and the propensity to barter - one is heavily decontextualized and the remaining two are false, turning into Jell-O ${ }^{\mathrm{TM}}$ the foundation of economics itself. The irony resides in that Smith's intellectual strength is based on the ability to sustain a dual macro-dynamic theory of economic development and a micro-theory of market exchange, i.e. he argues that the growing division of labor is the basic cause of the growth of the wealth of nations, and this, in turn, is the result of 'a certain propensity in human nature ... to truck, barter, and exchange one thing for another'. 7 Adam Smith was so eager to overturn the conventional wisdom of his day, objecting to the notion that money was a creation of government (which in Lockean fashion was to be limited to protect private property), that he invented a fantasy world of primitive people who bartered all the way until it became burdensome and they invented money - even though all available ethnography, from the Americas to the Pacific and to Africa, indicates that such a place never existed and thus money did not come from it. ${ }^{8}$

The fact that the foundational myth of economics is false is of the utmost importance. It follows from the make-believe land of barter that property, money and markets precede political institutions, constituting

4 John Cannon, Aristocratic Century: The Peerage of Eighteenth-Century England (Cambridge University Press 1984) 3-5.

5 D. Milonakis and B. Fine, From Political Economy to Economics: Method, the Social and the Historical in the Evolution of Economic Theory (Routledge 2009) 16-20.

6 Karl Polanyi, The Great Transformation (2nd edn, Beacon 2001) 45-50.

7 Milonakis and Fine, op. cit., 16-17.

8 Caroline Humphrey, 'Barter and Economic Disintegration' (Mar., 1985) Man, New Series, 20(1): 48-72. 
the foundation of human society, and even that there is a thing called 'the economy' operating by its own rules, separate from moral or political life, that economists could take as their subject matter. ${ }^{9}$ It is no wonder that most if not all basic textbooks in economics still imply that barter preceded money, dehistoricizing the subject matter in order to continue peddling the idea that there is a discipline called economics which is independent from the social sciences. ${ }^{10}$ There is an answer to such a racket, though, and it can be found in economic history - a discipline which, ironically, economists kicked out of their 'cool boys treehouse club' a long time ago.

Many identify the breaking moment when political economy started to properly morph into economics with the 'Methodenstreit' - an acrid debate between the German Historical School and the Austrian School of economics, or Gustav von Schmoller versus Carl Menger, and which circled around what the proper method of economic analysis should be. ${ }^{11}$ The orthodoxy of our time paints this clash as a no-holds-barred brawl between two polar opposites, but that is not accurate. They were discussing the nature of their 'science', its tasks and its limits, with Schmoller calling for the inclusion of social phenomena into economic axiomatic analysis via empirical-historic studies, while Menger pushed for abstraction and deduction - and, in reality, the latter wanted to turn political economy into a 'science of the laws of the economy' while the former went even further by stating that the practical purpose ought to be prediction and with it the practical domination of reality. ${ }^{12}$ Henceforth, Schmoller wanted to keep economics in the realm of the social sciences and, unlike Menger, use induction and deduction, though at the end both envisioned a morphing of political economy into a science. Therefore, the real schism did not start here but originated way before.

9 David Graeber, Debt: The First 5,000 Years (Melville House 2012) 21-28.

10 Carl Menger, The Origins of Money (Ludwig von Mises Institute 2009) 19-21; Friedrich von Wieser, Social Economics (Greenberg 1927) 5; Paul Samuelson, Economics (19th edn, McGraw-Hill 2000) 40; Gregory Mankiw, Principles of Economics (South-Western 2012) 620; Richard Lipsey and Colin Harbury, First Principles of Economics (2nd edn, Oxford University Press 2004) 18; Roberto Medina, Principles of Economics (Rex 2003) 227; Alfred Marshall, Principles of Economics (unabridged 8th edn, Cosimo 2009) 276.

11 Marek Louzek, 'The Battle of Methods in Economics: The Classical Methodenstreit - Menger vs. Schmoller' (2011) American Journal of Economics and Sociology 70: 439-463.

12 Karl Häuser, 'Historical School and "Methodenstreit"' (1988) Journal of Institutional and Theoretical Economics 144(3): 532-542. 
Despite Smith's shortcomings he seemed to be well aware of the pitfalls of pure deduction, ${ }^{13}$ and, accordingly, his method, 'though combining throughout a vein of unsound a prior speculation, was in a large measure inductive' ${ }^{14}$ - sometimes even in a chaotic manner. ${ }^{15}$ It is then said that with David Ricardo (coincidentally the only classical economist devoid of training in moral sciences) political economy stripped itself of historical or empirical references and absolutely championed the abstract/deductive method. ${ }^{16}$ Ricardo is, however, also a strange specimen on the long road towards the neoclassical orthodoxy despite his search for 'laws' as in natural sciences and through the use of logic in order to reach abstractions and simplifying assumptions. ${ }^{17}$ For example, in opposition to Bentham, he frowned upon individualism and employed a more collectivist type of reasoning (even using social class!) when focusing on the quantity of labor as the essence of value - which is perhaps the reason why Marx sided with Ricardo and also why conservatives felt uncomfortable with the conflict of capital and labor inference made by socialists from his theory of income distribution. ${ }^{18}$ Ricardo then is the one who caused the first major shakedown in political economy and gave the world (and economics) something as hilarious as it is stereotypical of economists, i.e. what Schumpeter called the 'Ricardian vice', or, in layman terms, the construction of abstract, highly restrictive models which are then applied directly to the complexities of the real world. ${ }^{19}$

However, there were attempts at rescuing Ricardianism, and not just from small thinkers but intellectual behemoths such as John Stuart Mill. For Mill, economics was fully hypothetical and it could not do anything

13 Arthur W. Brian, 'Inductive Reasoning and Bounded Rationality' (1994) The American Economic Review, 84(2): 406-411.

14 T.E. Cliffe Leslie, 'The Political Economy of Adam Smith' Fortnightly Review, 1 November $1870<$ http://socserv.mcmaster.ca/econ/ugcm/31l3/leslie/ leslie01.html> accessed 21 April 2017.

15 H.J. Bitterman, 'Adam Smith's Empiricism and the Law of Nature, Parts I-II' in John Cunningham Wood (ed.), Adam Smith: Critical Assessments (Routledge 1993) 195-199.

16 Milonakis and Fine, op. cit., 20-21.

17 Ibid 22.

18 Phyllis Deane, 'The Scope and Method of Economic Science' (1983) The Economic Journal 93(369): 1-12.

19 Esben Sloth Andersen, Schumpeter's Evolutionary Economics: A Theoretical, Historical and Statistical Analysis of the Engine of Capitalism (Anthem 2009) 354. 
other than to abstract. ${ }^{20}$ Therefore, he qualified ethically the caricature of the Benthamite hedonist and then called for economics - if it wished to be practically relevant - to consider a broader range of social and ethical matters beyond what 'economists are accustomed to examine'. ${ }^{21}$ In the case of Marx, his furtherance of a 'real positive science' in opposition to a mere echoing of the Moralität - other than the ethical living akin to class commonality, of course 22 - goes hand in hand with a systematic construction of a materialist edifice, i.e. quantitative and qualitative assessment of how surplus value is extracted, a framework of interpretation based on class relations derived from the latter, the inherent dichotomy that follows, and the dynamics by which, according to Marx, such structures are reproduced. ${ }^{23}$ Quite revealing is that both Mill and Marx (as so many others before and after) sincerely thought they were 'doing science', i.e. stating 'laws' - though, at the same time, their value judgements diverged, for example regarding the gradual fall in the general rate of profit. ${ }^{24}$ The most ironic part of this whole story, up to this point, is that the only economic school that called for historically concrete and nationally specific analysis, rejecting both laissez-faire capitalism and Marxist socialism, ended up being pushed aside as a distinct discipline altogether, i.e. the historical school. ${ }^{25}$

How was it possible for a respectable empirical research school to be defeated by deduction-loving, Benthamite utilitarian marginalists, i.e. the forefathers of the neoclassical school? Such a surprising turn of events may be explained by the following factors: (a) at the end of the nineteenth century the natural sciences were making great progress with the aid of mathematical tools; (b) the marginal technique of analysis helped not to disturb the belief in a self-regulating economic system, giving economists a sense of theoretical progress; and (c) Walras, Jevons, and Menger, the figureheads of 'scientific economics', resided in different countries and that gave economists a sense of international consensus. ${ }^{26}$ Conjectures aside, what is explicitly found in writings and debates

20 John Stuart Mill, Principles of Political Economy with Some of their Applications to Social Philosophy (London 1871) 147.

21 Milonakis and Fine, op. cit., 30-33.

22 Michael Rosen, 'The Marxist Critique of Morality and the Theory of Ideology' (2000) Morality, Reflection and Ideology 21-43.

23 Milonakis and Fine, op. cit., 60-70.

24 William H. Shaw, Marx's Theory of History (Stanford University Press 1978) 91-93.

25 Milonakis and Fine, op. cit., 73-82.

26 Deane, op. cit. 
is that marginalists sought to transform economics from an art to a pure science, ${ }^{27}$ and their lives reflected such an aspiration. Take Jevons, for example. The Englishman's innovation was to relocate the basis of economy from psychology to physiology - during a time when Thomas Huxley's hypothesis of 'animals as automata' suggested to Jevons that mental phenomena could be measured and objectively accessible, and so, henceforth, human wants could be reframed in terms of mechanics. ${ }^{28}$ The crude hostility of Jevons towards Mill is well documented, and no wonder, as Mill had committed the great sin of reinterpreting utilitarianism, and it was precisely Jevons' reliance on Bentham's sketchy pain/ pleasure equation that allowed him to introduce the mathematical model of constrained maximization. ${ }^{29}$ Walras, in turn, was so convinced that pure science was natural science that he, unpretentiously and subtly, gave his book the title Elements of Pure Economics ${ }^{30}$ - the same book in which he categorically defines his art (or science) as "the theory of the determination of prices under a hypothetical régime of perfectly free competition' and goes on to assert that 'the sum total of all things, material or immaterial, on which a price can be set because they are scarce (i.e. both useful and limited in quantity), constitutes social wealth', concluding 'hence pure economics is also the theory of social wealth'. ${ }^{31}$ And, finally, Menger, who, as we saw, was Schmoller's nemesis, added the other characteristic which neoclassical economics had faithfully inherited from marginalists, i.e. atomism, better known as methodological individualism; in his own words 'the nation as such is not a large subject that has needs, that works, practices economy, and consumes' and then continued by denying that the phenomena of the national economy are an expression of the life of a nation as such, saying that 'they are, rather, the results of all the innumerable individual economic efforts in the nation, and they therefore are not to be brought within the scope of our theoretical understanding from the point of view of the above fiction'. ${ }^{32}$ They, together, can be attributed with the

\footnotetext{
27 Milonakis and Fine, op. cit., 94.

28 Harro Maas, William Stanley Jevons and the Making of Modern Economics (Cambridge University Press 2005) 153-154.

29 R.D. Collison Black, 'Jevons, Marshall and the Utilitarian Tradition' in Ackerman et.al. (eds), Human Well-Being and Economic Goals (Island Press

30 Milonakis and Fine, op. cit., 95.

31 Léon Walras, Elements of Pure Economics (Routledge 2003) 40.

32 Carl Menger, Investigations into the Method of the Social Sciences with Special Reference to Economics (Mises Institute 2009) 93.
} 1997) 75. 
transformation of political economy into economics (a general theory with universal applicability, valid in all social systems ${ }^{33}$ ), which was explicitly articulated later by Alfred Marshall.

However, this is not the end of the story. As with any field of knowledge that aspires to objective value while its material is subjective in nature, economics is bound to be plagued with tensions. Marshall himself was never capable of moving from the partial equilibrium of micro to macroeconomics, not only due to how the analytics crumbled when aggregated but also because of the need to incorporate noneconomic factors into the mix when attempting to do so. ${ }^{34}$ Moreover, he warned against widening the scope of economics for fear of losing precision - in his own words:

there is a large debateable ground in which economic considerations are of considerable but not dominant importance; and each economist may reasonably decide for himself how far he will extend his labours over that ground ... $\mathrm{He}$ will be able to speak with less and less confidence the further he gets away from his central stronghold, and the more he concerns himself with conditions of life and with motives of action which cannot be brought to some extent at least within the grasp of scientific method. ${ }^{35}$

The attempts to break from the orthodoxy ever since have been, while laudable, constrained to debate within the materialistic realm and without abandoning the scientific aspirations observed since Adam Smith. The case in hand is institutionalism and, particularly, the work of Thorstein Veblen. The distinctive features of the institutionalists are: institutions as the basic template for all economy activity, of course; interdisciplinarity; historical specificity; breaking away from methodological individualism; critique of the neoclassical assumption of rational economic men; emphasis on dynamism in lieu of static equilibrium analysis; and, its most distinctive feature, the substitution of the mechanistic analogy for Darwinian evolutionary biology. ${ }^{36}$ Veblen, the paradigmatic institutionalist, used this intellectual edifice to offer an explanation of modern civilization, when saying 'now, business enterprise and the machine process are the two prime movers in modern culture; and the only recourse that holds a promise of being effective, therefore, is a recourse to the workings of

\footnotetext{
33 Milonakis and Fine, op. cit., 99.

34 Ibid, 130-131.

35 Alfred Marshall, Principles of Economics (unabridged 8th edn, Cosimo 2009) 643.

36 Milonakis and Fine, op. cit., 159-162.
} 
business traffic' 37 - where business enterprise is the leisure class driven by pecuniary gain through investment for profit, while the machine process refers to efficiency engineers making goods, driven by mechanical efficiency and workmanship. Once he had the 'big bang' moment figured out, he rejected biological determinism and the idea that social phenomena could be explained in terms of either the individual or society alone, ${ }^{38}$ and built his evolutionary scheme on the concept of habits of thought (in opposition to the hedonistic rationality of marginalism and the conscious class conflict of Marxism), where the part not settled by the society and each individual's employment consisted of the drive to turn things to human use (workmanship), the propensity for explaining the external world using imagination (idle curiosity), and the instinct to care for the welfare of others (parental bent). ${ }^{39}$ Armed with the conflict of business enterprise and machine process classes as ethos of the modern world and a human behavior structure, Veblen then attempts a historical account of how the leisure class originated with the invention of ownership and how, as an institution, it can be analyzed using the dichotomy of conspicuous consumption (defined as culturally determined and predatory) vs. subsistence consumption - which, in turn, denotes negative instincts in relation to positive drives, i.e. antipathy to useful effort and emulation (love of praise ${ }^{40}$ ). For Veblen, all these instincts, plus their defining role upon the class they represent, are culturally defined and become fluid as technological advances unfold. ${ }^{41}$

By the twentieth century economics had fully established its highly mathematized technical toolbox and transitioned from the study of how to create wealth to the 'science of choice', at which point it was ready to start attempting the colonization of other social sciences. ${ }^{42}$ However, because the economic edifice was built on sand rather than rock, with the orthodoxy aberrantly reduced to its own echo chamber of assumptions, the infighting continued - though every day, more and more, taking place within the confines of the orthodoxy's invented language and tools.

37 Thorstein Veblen, The Theory of Business Enterprise (Blackmask 1999) 127.

38 Geoffrey M. Hodgson, The Evolution of Institutional Economics: Agency, Structure and Darwinism in American Institutionalism (Routledge 2004) 134.

39 Warren Samuels, The Founding of Institutional Economics (Routledge 1998) 23.

40 John P. Diggins, Thorstein Veblen: Theorist of the Leisure Class (Princeton University Press 1999) 122-123.

41 See Figure 2.1 in Chapter 2 for a graphic explanation of Veblen's theories.

42 Milonakis and Fine, op. cit., 219. 
Weber, for example, tried to keep a broader notion of economics alive and to show that economic phenomena did not occur in a social vacuum. To do so, he came up with a taxonomy for a more systematic study of economic phenomena, economically relevant phenomena, and economically conditioned phenomena - and then developed a thorough account of economic action, its types (instrumentally rational, value rational, affectual, and traditional), and subjective interplay under the mechanism of the law. ${ }^{43}$ Such a drive is commendable yet it is fair to note that Weber, too, was invested in making sociology like economics, i.e. ethically neutral, value-free and strictly separated, something which still causes problems as the creation of concepts in social sciences necessarily imply the use of values. ${ }^{44}$

Weber's conundrum was shared by Schumpeter, the other figure associated with Sozialökonomik. For Schumpeter (perhaps in a drive to add further layers to economic orthodoxy), the process of economic analysis had to be: first, for the statistician to arbitrarily create models intending to portray certain aspects of reality while taking others for granted; second, to place the schemata against the backdrop of historical facts which provide the institutional framework, even going back to what anthropology has to offer; and, third, to incorporate 'Wirtschaftssoziologie', i.e. to describe and interpret social facts because if 'economic analysis deals with the questions how people behave at any time and what the economic effects are they produce by behaving ... economic sociology deals with the question how they came to behave as they do' ${ }^{45}$ Another contribution from Schumpeter, and quite a relevant one, is his dynamic analysis of economic development. Unlike Walras', Schumpeter's theory is dynamic as it incorporates change from within, much like Marx; although, unlike Marx, Schumpeter's methodological individualism makes him identify economic change as initiated by the individual, whether via the introduction of a new good, a new method of production, a new market, new source of supply of raw materials, or a new organization of an industry - or what Schumpeter calls enterprise, i.e. setting up a concern around a new idea, which he sees as different to management or the mere administration of it. ${ }^{46}$ This approach by

43 Max Weber, Economy and Society: An Outline of Interpretive Sociology (University of California Press 1978) 63-67.

44 Douglas Vickers, Economics and Ethics: An Introduction to Theory, Institutions and Policy (Praeger 1997) 64-65.

45 Joseph A. Schumpeter, History of Economic Analysis (Routledge 1997) $12-21$.

46 Milonakis and Fine, op. cit., 210-212. 
Schumpeter is perhaps one of the most interesting ones when paired with Veblen's model of the management and the engineer classes. ${ }^{47}$

Economics was still to be narrowed down even further by the addition of positivism. Competing schools aside, what unites positivists is the ironclad belief that only what our senses perceive is real and, henceforth, science ought to be cleared from any metaphysical considerations and its methodological premises ought to span throughout both the physical and the social fields. Behind this is the old discussion about the 'unity of science', which is perniciously crucial for economists because, first, if they can consider themselves scientists then there is a respectability they can share with physicists, chemists, biologists, etc., and, second, because unifying the sciences provides methodological guidance and hypothetical justifications, plus an upper hand in matters of policy by cutting through any deliberative process involving complex matters of high social impact. ${ }^{48}$

Enter Milton Friedman. In what is said to be the most cited paper in the history of economic methodology, ${ }^{49}$ Friedman stated that positive economics is an objective science in the same sense as any physical science and, as it is independent of any particular ethical position or normative judgment, its sole task is to produce generalizations used to make predictions - which, in turn, shall only be judged by their accuracy, not their realism or their underlying assumptions. ${ }^{50}$ Needless to say, Friedman's reputation hasn't been dented one bit since then - despite being questioned by methodologists and philosophers alike, for example for confusing theories made solely for prediction purposes and those which are made to provide an explanation, ${ }^{51}$ or for having been proven outright to have made a fallacious statement regarding prediction as the sole testability of a hypothesis, which also, to add insult to injury, does not follow from the premise that a good hypothesis provides valid predictions within the phenomena it intends to explain. ${ }^{52}$ It is not hard to see why an instrumentalist view, shedding light on the realism of

47 Veblen, op. cit.

48 Jordi Cat, 'The Unity of Science' in Edward N. Zalta (ed.), The Stanford Encyclopedia of Philosophy (2017) <https://plato.stanford.edu/archives/spr2017/ entries/scientific-unity/> accessed 1 May 2017.

49 Milonakis and Fine, op. cit., 235.

50 Milton Friedman, 'The Methodology of Positive Economics' in Essays in Positive Economics (University of Chicago Press 1966) 3-16, 30-43.

51 Bruce Caldwell, Beyond Positivism (Routledge 1994).

52 Daniel Hausman, The Inexact and Separate Science of Economics (Cambridge University Press 1992) 162-167. 
assumptions, was so palatable to economists. ${ }^{53}$ Think about that for a second: if one is told that tomorrow will be a good day, and it happens that, indeed, the day turns out to be good, the predictor is considered a sage, even though the underlying premise was that Saturn aligned with Mars according to the Tarot cards.

The last three great names in economics within our brief account, Mises, Hayek, and Keynes, reinforce with their appearance what has been quite clear so far: on one side, they all provided heavy blows to mainstream economics which were either ignored or chased away by a pitchfork-carrying mob, while, at the same time, they perpetuated their discipline's misgivings. Austrians, for example, made a pretty good case for how equilibrium is impossible, while at the same time balancing this with the positive role of the market in coordinating inventiveness and discovery; ${ }^{54}$ what Mises is mostly remembered for in the mainstream is his methodological individualism and the belief in economic subjectivism as its source of objectivism, for example:

because it is subjectivistic and takes the value judgments of acting man as ultimate data not open to any further critical examination, it is itself above all strife of parties and factions, it is indifferent to the conflicts of all schools of dogmatism and ethical doctrines, it is free from valuations and preconceived ideas and judgments, it is universally valid and absolutely and plainly human. ${ }^{55}$

As for Hayek, he bravely left us with two pearls of wisdom: first, that a good economist is never only an economist, as there are no problems which can be adequately answered by a single discipline, and, second, his scathing critique of 'scientism' or the attempt to apply the methods of the natural science in the social ones. ${ }^{56}$ Good things in life are fleeting, though. Hayek is remembered today for his defense of methodological individualism, for he wrote that 'there is no other way towards an understanding of social phenomena but through our understanding of individual actions directed towards other people and their expected behaviour';57 and, also, for his coining of the idea of the spontaneous

53 Christopher Mackie, Canonizing Economic Theory: How Theories and Ideas are Selected in Economics (Routledge 2015).

54 Milonakis and Fine, op. cit., 246.

55 Ludwig von Mises, Human Action: A Treatise in Economics (The Scholar's edn, Ludwig von Mises Institute 1998) 21.

56 Milonakis and Fine, op. cit., 260.

57 Friedrich Hayek, Individualism and Economic Order (University of Chicago Press 1958) 6. 
order of markets, which follows from his assertion that "many of the institutions on which human achievements rest have arisen and are functioning without a designing and directing mind ... and the spontaneous collaboration of free men often creates things which are greater than their individual minds can ever fully comprehend' ${ }^{58}$ In the case of Keynes, it can be said that he saved face for economics by divorcing microeconomics from macroeconomics, helping thus to facilitate answers to issues which the former was incapable of addressing, i.e. the business cycle, the financial system and massive unemployment. ${ }^{59}$ Sadly, in his attempt to broaden the discipline, Keynes committed a heresy and, with it, the fate of his legacy was sealed: he trashed the individualistic leaning of neoclassical economics by building an aggregate model of the economy as a whole, as an attempt to respond to the question of the determinants of supply and demand for aggregate output, and, in the process, he stated that there was no such thing as an invisible hand concocting social value out of private self-interest. ${ }^{60}$ This was not taken lightly by his detractors. Once the post-war boom was over and Keynesianism started to decline, general equilibrium proponents and monetarists started to creep out of their caves, ${ }^{61}$ leaving behind shameful episodes, for example Lorie Tarshis, a Canadian economist who brought the first proper Keynesian textbook to the U.S., and who suffered boycotts and disrepute because McCarthyists labeled him as too sympathetic to communism (with a book inspired by Keynes of all things!). ${ }^{62}$

Today, the predominance of the neoclassical dogma continues despite its blind spots, i.e. stability, the mere existence of equilibrium, and the absence (still!) of a rationale for money, not to mention the known vices of sci-fi assumptions, hyper-abstract analysis, and empirical emptiness. Worst of all, as the definition of what constitutes the economy has shifted, by treating the non-economic as if it were reducible to market activity, anything that can be said to involve scarcity and, henceforth, choice, has been colonized by economics, infecting entire fields of study with its deductivism, determinism and conceptual impoverishment. ${ }^{63}$ Not even the corners where there is no market per se are safe, as Richard

58 Ibid 7-8.

59 Milonakis and Fine, op. cit., 273.

60 Phyllis Deane, The Evolution of Economic Ideas (Cambridge University Press 1993) 182.

61 Milonakis and Fine, op. cit., 275.

62 Philip Arestis and Malcolm Sawyer (ed.), A Biographical Dictionary of Dissenting Economists (Edward Elgar Publishing 2000) 657.

63 Milonakis and Fine, op. cit., 243, 296, 298. 
Posner, one of the new religion's priests, candidly puts it: 'The expanded range of economic analysis of law was facilitated by the expanding application of the economist's model of rational choice to nonmarket behavior' ${ }^{64}$ Even best-selling economists claim in their pop culture books that their discipline is the science of life and could potentially explain everything short of the universe!65 The reasons behind this modesty are as complex as virology, i.e. on one hand, the outright mathematical approach of the neoclassicals and their claim of precision add to the aesthetic qualities of the discipline and its tools work analytically well within the restricted, heavily assumed, and mechanical sexiness of its models. ${ }^{66}$ On the other hand, 'the more specialized a thought community is and the more restricted in its content, the stronger will be the particular thought nexus among the members' ${ }^{67}$ Translated, this refers to an esoteric circle with its own consciousness, inextricable language and self-evident truths, a fenced club armed with a unique overarching directional narrative.

Based on this abridged methodological history of economics we can confidently affirm that, even though the 'crème de la crème' of neoclassical economists claims that, unlike macro, microeconomics is a unified and uncontroversial field, ${ }^{68}$ this is not true. Suffice it to look at the splinter of schools which have taken shape since the time Smith invented economics.

Figure 1.1 leaves Keynesian, developmentalist and Schumpeterian schools out, mostly to serve the purpose of illustrating equidistant economic schools in their variation. ${ }^{69}$ They all share, though, some general assumptions, chief among them being some degree of rationalism of the units conforming an artificially isolated subject matter. While neoclassicals see the economy as atomized, with consumption as its paramount element, and economic change as based on individual choices within a free market, classics talk about change through capital accumulation, focus on production and tend to see classes. Marxists are in the

64 Richard Posner, Frontiers of Legal Theory (Harvard University Press 2004) 34 .

65 Tim Harford, The Logic of Life (Abacus 2009) x-xxii.

66 Deane, The Evolution of Economic Ideas, op. cit., 108-109.

67 Ludwik Fleck, Genesis and Development of a Scientific Fact (University of Chicago Press 1979) 106-108.

68 G. Chris Rodrigo, 'Micro and Macro: The Economic Divide' (2012) International Monetary Fund, Finance and Development, 31 January <http:// www.imf.org/external/pubs/ft/fandd/basics/bigsmall.htm> accessed 6 May 2017.

69 Ha-Joon Chang, Economics: A User's Guide (Penguin 2014) 166-169. 


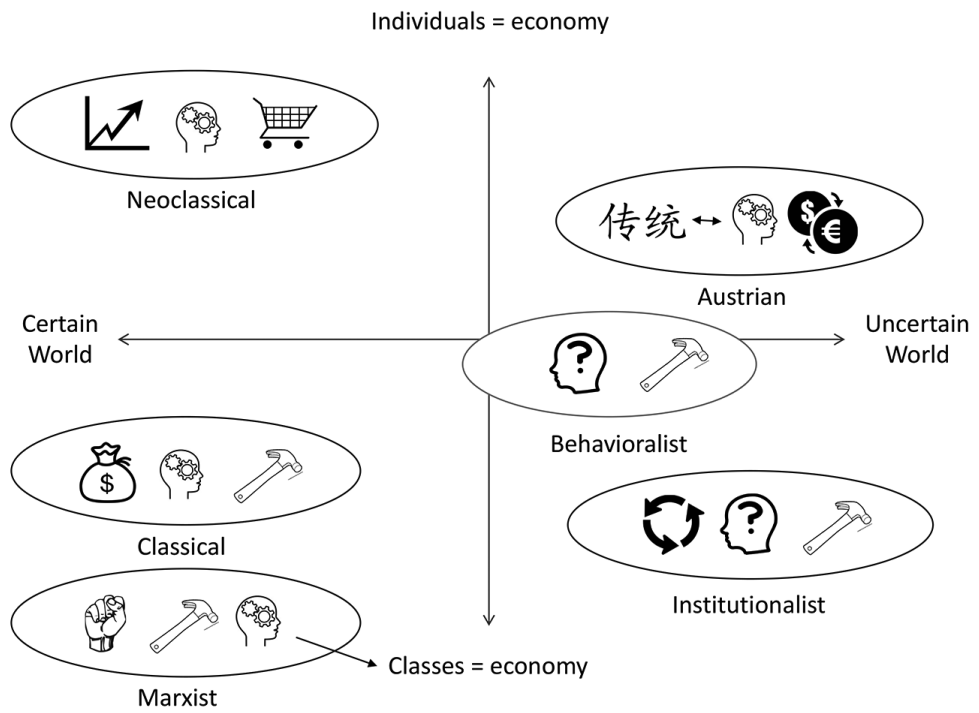

Figure 1.1 Economic schools

same quadrant as classics, with the difference of change through class struggle, though also perceiving the world as certain, made of iron laws or laws of motion. On the opposite side of the spectrum, the uncertain world, institutionalists and behavioralists do not rely on a hyperrational individual, yet Austrians see individuals as rational in terms of tradition while instinct, habits and beliefs dominate the rationality view of institutionalists, who also perceive production rather than exchange as the crucial part of the economy. For the institutionalists, moreover, change takes place precisely through the interaction between individuals and institutions rather than class struggle, capital accumulation, or individual choices.

\section{THE 120 DAYS OF NEOCLASSICAL ECONOMICS}

The implication of economics not being a science is that it is about politics. And, as such, it is in constant internal strife, governed by different ideologies throughout the various stages of its history. This, in turn, makes economics, as with any other political philosophical discipline, susceptible to valid criticism based on competing ideologies, and whichever school is dominant at any given moment can claim predominance over the others in matters of policy, though not by virtue of some 
sort of final, undisputable 'scientific eschatology'. Neoclassical economics is the best example, for its reign is current and, thus, easier to grasp. The putative father of economic democracy, Karl Polanyi, elegantly summarized in his magnum opus The Great Transformation the myth of rational choice, profit-maximizing individuals, as follows: 'The outstanding discovery of recent historical and anthropological research is that man's economy, as a rule, is submerged in his social relationships', then goes on to say that

he does not act so as to safeguard his individual interest in the possession of material goods; he acts so as to safeguard his social standing, his social claims, his social assets. He values material goods only in so far as they serve this end. Neither the process of production nor that of distribution is linked to specific economic interests attached to the possession of goods; but every single step in that process is geared to a number of social interests which eventually ensure that the required step be taken. These interests will be very different in a small hunting or fishing community from those in a vast despotic society, but in either case the economic system will be run on non-economic motives. ${ }^{70}$

As authors like Rist point out, people have produced, consumed, saved, distributed and exchanged since the dawn of times (hence the 'economy' has always existed, in the same way that climate exists regardless of meteorologists) though economic 'science', at some point, instead of observing that people have not regarded economic phenomena distinctively from social life, political power, religion, myths and social obligations, chose to view such a complex and vast web of relations chiefly from the perspective of division of labor, market exchange, individual rationality and the pursuit of utility, mechanizing the richness of human relations into a reductionist set of calculable operations triggered by self-interest. ${ }^{71}$

True, economics, with its seeds of what was to become the neoclassical dogma, is a product of a specific historical time and, in hindsight, can be hailed as good, i.e. Smith, Bentham, Condorcet, and others were Enlightenment thinkers whose political philosophy was a response to an imperialism deemed unworkable, dangerous and immoral based on reasons such as free trade, self-determination, cultural integrity, or,

70 Karl Polanyi, The Great Transformation: The Political and Economic Origins of Our Time (Beacon Press 2002) 49.

71 Gilbert Rist, The Delusion of Economics: The Misguided Certainties of a Hazardous Science (Zed Books 2001) 20-21. 
simply, due to the irony of civilized nations engaging abroad in uncivilized practices of despotism, corruption, and lawlessness. ${ }^{72}$ It is thus explicable that in order to philosophically displace authority away from the figure of the king or prince, the Enlightenment thinkers, as in the case of Herder, for example, based their ethical claims on laws of nature both as a social fact and a moral norm, ${ }^{73}$ to the extent that freeing human nature from the artificial constraints of religion and society was perceived as a way to promote 'the science of man' ${ }^{74}$ In such a drive, progressive thinkers embraced the fruits of the new scientific discoveries, for example mechanistic physics and, with it, concepts such as equilibrium, balance, mass, elasticity, forces, atomization, circuit, flows, friction, leverage, boost, etc. ${ }^{75}$ Economics was envisioned, thus, to be some sort of social physics; however, it fails precisely in that same respect because nature exists independently from human activity, while the economic life does not, no matter how much economists, in their parlance and assumptions, seem to pretend otherwise. Taking this analogy even further, it is interesting to note that when there are paradigm shifts in science, ${ }^{76}$ not only do scientific beliefs about nature change but also the standards and criteria of scientific judgment, 77 though when the turn came for economics to follow suit and behave like a science it failed to do so. The classical mechanistic theory on which economics was founded saw time as reversible since a given system subject to change can be restored to the initial state with a reverse change, reproducing the phenomenon back and forth for the purpose of prediction (something which still has applicability in terms of celestial bodies moving in the void without friction). However, thermodynamics ended with the reversibility of classical mechanics by discovering transformative matter and entropy, and in order to 'remain' a science economics should have had to incorporate the discoveries of the new physics, but it did not. ${ }^{78}$ Even though economists did alter their view on value, the fundamentals remained glued together

\footnotetext{
72 Sankar Muthu, Enlightenment against Empire (Princeton University Press 2003) 3-5.

73 Ibid 247.

74 Thomas L. Hankins, Science and the Enlightenment (Cambridge University Press 1985) 179.

75 Rist, op. cit., 26.

76 Thomas S. Kuhn, The Structure of Scientific Revolutions (University of Chicago Press 2012) 44-51.

77 Hugh G. Gauch, Scientific Method in Practice (Cambridge University Press 2003) 85.

78 Rist, op. cit., 28-29.
} 
by their mechanistic ideal. This is one of the many fundamental reasons why even some economists call their discipline a pre-science ${ }^{79}$ at best. After reviewing the frontrunner economic journals, it is fair to say that there are some economic researchers who accept that their discipline requires revisions, mostly (a) the canonical model of the self-interested material-payoff-maximizing actor, and (b) the belief that preferences over economic choices are exogenous rather than shaped by everyday social interactions - although they (wrongly) tend to emphasize that such revisions should not imply that economists abandon the rational-actor framework. ${ }^{80}$

Speaking about the rational homo economicus used for the economists' descriptive and normative models, this is yet another good example of both the danger of creating theories which neither explain nor predict reality and of being seduced by the esoteric circles of knowledge, as Fleck pointed out. The standard economic theory of consumer behavior is, of course, based on a rational maximizing model, and in the late 1970s Kahneman and Tversky demonstrated with prospect theory that humans make choices involving risk in violation of the axioms of expected utility theory, ${ }^{81}$ i.e. not in a rational manner but as quite susceptible to losses, gains, perception of ownership, etc. Borrowing from this research, Thaler correctly stated that the orthodox economic model of consumer behavior is essentially one of 'robot-like experts' which, needless to say, fumbles at predicting behavior - with the added danger that economists rarely distinguish between normative and descriptive models. ${ }^{82}$ In other circumstances, as Kuhn would say, this happy breakthrough would have caused a rewriting of the discipline's textbooks. ${ }^{83}$ Not so in economics. Instead of producing the torches and pitchforks, Kahneman got a Nobel Prize and, in an appalling twist, went on to say that the oversimplified and unrealistic assumptions in basic economics texts must be kept there because prospect theory could be confusing and demoralizing to young economics students - which is, basically, a way of perpetuating the

79 Steve Keen, Debunking Economics: The Naked Emperor Dethroned? (Zed Books 2011) 158.

80 Joseph Henrich, Robert Boyd, et al., 'In Search of Homo Economics: Behavioral Experiments in Fifteen Small-Scale Societies' (May 2011) The American Economic Review 91(2): 73-78.

81 Daniel Kahneman and Amos Tversky, 'Prospect Theory: An Analysis of Decision Under Risk' (1979) Econometrica 47(2): 263.

82 Richard Thaler, 'Toward a Positive Theory of Consumer Choice' (1980) Journal of Economic Behavior and Organization 39-60.

83 Kuhn, op. cit., 136. 
theory-induced blindness which he himself criticizes. ${ }^{84}$ This baffling turn of events - or lack thereof - which otherwise marked the foundation on which Thaler built behavioral economics ${ }^{85}$ is evidence of the cognitive inertia dominating the mainstream. Even pop culture sources of behavioral economic thought speak of Kahneman and Tversky as redefining the way humans think, ${ }^{86}$ and, yet, the rational homo economicus keeps lurking in the background.

Let's look at the cornerstone of the principle of utility, i.e. Benthamite philosophy, lambasted with gusto by several thinkers as we have seen earlier. For Bentham,

nature has placed mankind under the governance of two sovereign masters, pain and pleasure. It is for them alone to point out what we ought to do, as well as to determine what we shall do. On the one hand the standard of right and wrong, on the other the chain of causes and effects, are fastened to their throne. They govern us in all we do, in all we say, in all we think: every effort we can make to throw off our subjection, will serve but to demonstrate and confirm it. ${ }^{87}$

The fact remains, though, that there is no unit of accounting for either 'pain' or 'pleasure' - there is not even a common way of measuring pleasures within the same individual! And, still, in order to be able to establish constant and uniform laws, economics had to anchor economic value in utility in an artificial way, i.e. define utility in a non-moral way, so it would not depend upon value judgments, and account for rational choice, which, according to Jean-Baptiste Say, was done by the tautology of utility as desirability plus scarcity equals price, yet with price also being defined as the measure of utility. ${ }^{88}$ In any case, economists went through with it and came up with the concept of 'utils', which is the unit of satisfaction derived from consuming a commodity and which is always positive, although it drops gradually as more units are consumed, in what

84 Daniel Kahneman, Thinking, Fast and Slow (Penguin 2011) 278-288.

85 Daniel Kahneman, 'Biographical' (Nobel Media, 2014) <http://www. nobelprize.org/nobel_prizes/economic-sciences/laureates/2002/kahneman-bio.html> accessed 11 July 2017.

86 Freakonomics Radio, 'The Men Who Started a Thinking Revolution' (4 January 2017) 3:47-3:55, comments by Stephen J. Dubner, podcast host <http://freakonomics.com/podcast/men-started-thinking-revolution/> accessed 11 July 2017.

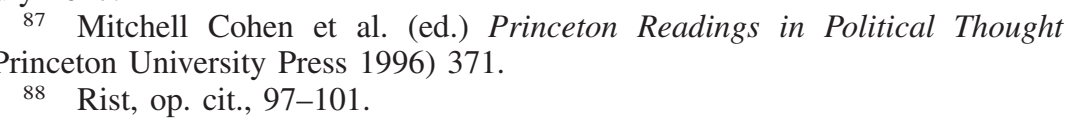


is called the law of diminished marginal utility. ${ }^{89}$ This core assumption by economists not only attempts to achieve an objective, precise measure of something as intrinsically subjective as personal satisfaction, but also, more worryingly: (i) the model's output keeps on ascending, plus it takes a maximum of two commodities, and going above whatever combination of two commodities equal in utils is considered irrational; and (ii) the law of demand derived from this one-person scenario behaves differently when extrapolated to a two-or-more-persons scenario, but is still used, by virtue of methodological individualism, to market demand provided certain conditions are met, and those conditions are, in essence, oneconsumer/one-commodity - which is rather strange since the goal of the law of demand is to explain how relative prices are set, though there is no 'relative price' at all if there is only one consumer and one commodity. ${ }^{90}$

Freedom is one of the most praiseworthy human ideals and using it to engage others through a market system has proven to be more fair and advantageous than its opposite. However, it is worringly narrow to study and depict human nature solely through the prism of rational choice imperialism. ${ }^{91}$ Society is not a collection of individuals with nothing in common except the maximization of utility - there is a social bond that ought to be integrated into the analysis. ${ }^{92}$ Even the most recent game theory experiments show what is, basically, commonsense, i.e. that in the animal world, selfishness, as opposed to a cooperative disposition, can provide a short-term advantage though in the long run it means extinction. ${ }^{93}$ And although this collection of criticisms about the pillars sustaining neoclassical economics may seem theoretical at first, several authors have argued convincingly that there are real life implications in treating political philosophy as an exact science. Cases in point are the recent financial crisis and the existential threat.

89 Fred M. Gottheil, Principles of Economics (Cengage Learning 2012) 109-113.

90 Keen, op. cit., 43-55.

91 Joseph Heath, 'Methodological Individualism' in The Stanford Encyclopedia of Philosophy (2011) <http://plato.stanford.edu/archives/spr2011/entries/ methodological-individualism/> accessed 6 May 2017.

92 Rist, op. cit., 47-51.

93 Christoph Adami and Arend Hintze, 'Evolutionary Instability of Zerodeterminant Strategies Demonstrates that Winning is Not Everything' (2011) Nature Communications 4, Nature Publishing Group <http://dx.doi.org/10.1038/ ncomms3193> accessed 8 May 2017. 
In the former case, Keen makes a succinct yet powerful case when saying that, first, among the logical conclusions of neoclassical economics is the correct pricing of financial assets by finance markets and the goodness of debt, both of which stimulated reckless behavior around what is now known as the subprime crisis; second, the bombastic mathematization of economics nurtured the creation of exotic and complex synthetic financial products (a.k.a. 'weapons of financial mass destruction'94); and, third, the upper echelons of financial regulation authorities are populated by neoclassical, and hence permissive, economists. ${ }^{95}$

As for the existential threat, most macro-economic models assume that growth can, and will, continue indefinitely, while the same logic applies at microeconomic level, with corporations faced with a grow-or-die scenario. Governments encourage this by debt-financed growth through taxing profits and treating interest payments on debt as tax deductible, which, in turn, feeds consumerism with an overload of advertising, cost-cutting rewards, raiding of pension funds, etc. ${ }^{96}$ Although it is difficult to assess if there is any other option that would not cause a social catastrophe, the pace of exploitation draws upon non-renewable resources and endangers the ecosystem through pollution by industrial production. ${ }^{97}$ An example of the world's dependence on material growth is the Gross Domestic Product (GDP), the standard tool which aggregates the total value produced in a country and which is the gold standard for measurement of growth, even though: (a) it does not record non-market transactions; (b) it excludes real human suffering by treating it as a mere externality; (c) it does not account for the destruction of goods freely provided by nature; (d) it is oblivious as to how the wealth is distributed; and (e) it does not evaluate the social desirability of market activities, effectively treating as equivalent the production of, for example, vegetables and nuclear bombs. ${ }^{98}$ It is for these reasons that when the GDP is

94 Edward Jay Epstein, 'Warren Buffet's Hidden Stake in Financial Weapons of Mass Destruction' (February 2009) Vanity Fair <http://www.vanityfair. com/news/2009/02/warren-buffetts-hidden-stake-in-financial-weapons-of-massdestruction> accessed 6 May 2017.

95 Keen, op. cit., 22.

96 Robert Ayres, Turning Point: An End to the Growth Paradigm (Earthscan 1998) 101-103.

97 Rist, op. cit., 129.

98 Ibid $120-122$. 
put to the test against other measurements, such as, for example, the Genuine Progress Indicator (GPI), ${ }^{99}$ the results do not track each other. ${ }^{100}$

\section{LAW AND ECONOMICS SITTING IN A TREE}

So, how did law fall prey to neoclassical economics? As ventured earlier, economics imperialism is facilitated by the shifting definition of what the field of study is, and, second, its overuse of calculus and statistics (the only real mathematics economics uses) lends it an air of respectability, which, in turn, fosters an esoteric circle - what is now commonly known as an 'echo chamber'.

It is understood that law and economics, as seen today, was born in the United States in the late 1950s, and, thanks to the influence of Richard A. Posner, it became an accepted and buoyant school of thought within the legal community from the 1970 s onwards. ${ }^{101}$ However, if we subscribe to the definition of law and economics as the application of economic theory and econometric methods to an examination of the law and legal institutions, it is no surprise to find a dissent throughout law and economics historians regarding its origins. While Richard Posner is seen as the scholar who brought law and economics into the academic spotlight, there are well-identified precursors such as Coase, while some authors even identify a well-structured attempt to apply economic tools to legal questions dating back to Commons, ${ }^{102}$ who, similar to the Staatswissenschaft (the German school mixing political economy and law), systematically inquired into how property and other rights were determined, historically and functionally, across different societies, attempting what could be called an explanatory science of rights based on economic

99 GPI: <http://gpiatlantic.org/gpi.htm>. Other alternatives are the Human Development Index (HDI), Ecological Footprint, Biocapacity Gini coefficient, and Life Satisfaction scores, all of which can be found online.

100 Ida Kubiszewski, 'Beyond GDP: Measuring and Achieving Global Genuine Progress' (April 2013) Ecological Economics 93: 57-68<http://www. elsevier.com/locate/ecolecon> accessed 2 May 2017.

101 Ejan MacKaay, 'History of Law and Economics' in B Bouckaert and G De Geest (eds), Encyclopedia of Law and Economics (Edward Elgar Publishing and University of Ghent 1996-2000) <http://encyclo.findlaw.com/0200 book.pdf> accessed 3 November 2012.

102 Lewis Kornhauser, 'The Economic Analysis of Law' in Edward N. Zalta (ed.), The Stanford Encyclopedia of Philosophy (Fall 2011 Edition) <http:// plato.stanford.edu/archives/fall2011/entries/legal-econanalysis/> accessed 3 November 2012. 
conditions. ${ }^{103}$ All in all, we subscribe to the idea that the economic analysis of law proper started with Bentham - who thought about how actors react to legal incentives and evaluate outcomes based on social welfare - and was then developed by Coase and his study of externalities and liability, until it reached its peak with Posner and his general textbook on law and economics. ${ }^{104}$

The theoretical approach championed by Bentham started from the premise of law as an instrument to serve the social good. This is in opposition to law as imbued by an immanent order of natural principle and by what is morally right. Instrumentalism is not a new development and it has a long lineage in the Judeo-Christian tradition, for example the Rabbinic analysis of Jesus' position regarding the law, when, according to Mark 2:27, tells the Pharisees who criticize the Apostles for plucking grain on the day of rest: 'the Sabbath was made for man, not man for the Sabbath'. ${ }^{105}$ This approach gained in strength in the course of the 20th century, when a culturally heterogeneous and class-differentiated population, increasingly secularized and swayed by the horrors of the two world wars and the crumbling of faith in the authorities enacting and enforcing the laws, started to hesitate about the mere existence of objective moral principles, holding itself to the Enlightenment ideals as neutral sources of all-solving principles. ${ }^{106}$ Of course, instrumentalism is not an exclusive analytical tool, as even Aquinas and other advocates of positions opposed to utilitarianism have made use of some variants of it. ${ }^{107}$ Even more, in the recognition of the different realms of the real world and the legal world itself a symbiotic instrumentality is implied. ${ }^{108}$

103 Mackaay, op. cit.

104 Louis Kaplow and Steven Shavell, 'Economic Analysis of Law' (1999) Harvard Law School John M. Olin Center for Law, Economics and Business Discussion Paper Series, Paper 251.

105 Chaim N. Saiman , 'Jesus' Legal Theory - A Rabbinic Interpretation' Villanova Law/Public Policy Research Paper No. 2007-15; (2007-2008) Journal of Law and Religion 23: $97<$ http://ssrn.com/abstract=992280> accessed 10 May 2017.

106 Brian Z. Tamahana, 'How an Instrumental View of Law Corrodes the Rule of Law' (2007) DePaul Law Review 56; St. John's Legal Studies Research Paper No. 06-0061 <http://ssrn.com/abstract=951518> accessed 11 May 2017.

107 Leslie Green, 'Law as a Means' HART-FULLER AT 50, Peter Cane, ed., Oxford: Hart Publishing; Oxford Legal Studies Research Paper No. 8/2009 <http://ssrn.com/abstract=1351304> accessed 13 May 2017.

108 Nicholas H.D. Foster 'The Theoretical Background: The Nature of the Actors in Corporate Social Responsibility' in Stephen Tully (ed.), Research Handbook in Corporate Legal Responsibility (Edward Elgar Publishing 2005). 
The worrying aspect of instrumentalism as experienced nowadays, though, is that the epistemological skepticism leading to the absence of objective moral foundations, paired with the idea that the public good is advanced as if by an invisible hand when individuals pursue their own good, undermines the existence of legal limits on law itself. ${ }^{109}$ As long as it is claimed that law can consist of anything and serve any end (once the formalities of its enactment are fulfilled), and its goal is reduced to satisfaction of mere materialistic needs, ${ }^{110}$ there is no balancing of competing interests but merely a zero-sum game where individuals or groups seek to influence law in their favor and wield its coercive force against opposing groups. ${ }^{111}$ If we accept that the citizenry obeys the law either because of fear of punishment or the belief that it serves the public good, the instrumentalist view of the law leaves the former reason as the only one standing - and that is a sad state of affairs. A clear example of this is Richard Posner himself, who not only is the champion of the mainstream law and economics school but also a judge. When presented with a case he claims to first ask himself what would be a reasonable result in the eyes of a lay person and then, having found the answer, check for legal obstacles for deciding in such a way. ${ }^{112}$ This pragmatic approach is, plain and simple, an individual (the judge) imposing opinions instead of the law, i.e. value decisions based on an individual's biases, hatreds, tendencies, ideology, phobias, interests, etc. which threatens the certainty required in a fair and functioning legal system. ${ }^{113}$ It is of crucial importance to analyze Posner's position, as he is not only key to this story but also his thought evidences law and economics' direct connection with Friedman's convenient 'as if' instrumentalism.114 According to Posner, economics is not reductionist but it builds models

109 Tamahana 'How an Instrumental View of Law Corrodes the Rule of Law', op. cit.

110 Brian Z. Tamahana, 'The Dark Side of the Relationship between the Rule of Law and Liberalism' St. John's Legal Studies Research Paper No. 08-0096 $<$ http://ssrn.com/abstract=1087023> accessed 9 May 2017.

111 Tamahana, 'How an Instrumental View of Law Corrodes the Rule of Law', op. cit.

112 'Tap Dancing: The New Republic Online Debate between Richard A. Posner and Philip B. Heyman' (01.31.2006), available on the Harvard Law School International Center for Criminal Justice website $<$ http://www.law. harvard.edu/programs/criminal-justice/posner-heymann-debate.pdf $>$ accessed 11 May 2017.

113 Tamahana, 'How an Instrumental View of Law Corrodes the Rule of Law', op. cit.

114 Friedman, op. cit., 3-16, 30-43. 
for predicting and controlling behavior, i.e. 'economics imagines the individual not as "economic man," but as - a pragmatist. As one who bases decisions not on sunk costs ... but on the costs to be incurred and the benefits to be reaped from alternative courses of action that remain open', and he then adds, 'nothing in economics prescribes an individual's goals ... but whatever his goal or goals, some or for that matter all of which may be altruistic, he is assumed to pursue them in forward-looking fashion by comparing the opportunities open to him at the moment when he must choose'. ${ }^{115}$ The only problem being that, as demonstrated by behavioralists, this is simply not true. This does not deter Posner, though, who literally calls for an instrumental, ethics-free law devoted to milking the benefits of the free market, ${ }^{116}$ and, coherently with this position, he doubles down elsewhere with a staunch defense of moral relativism, stating that the only measure of morality is its contribution to survival or other synthetic, temporary or sectarian goals, and that what he calls 'academic moralism' is helpless when contradicted by self-interest. ${ }^{117}$ Again, this is solid argumentation by Posner, except for the fact that a great deal of research shows that moral judgments and at least one of their preconditions, to distinguish between intentionality and outcome, is present in humans by the age of eight months, ${ }^{118}$ hence it is part of our 'pre-installed software'. Still, Posner is coherent with these ideas of his when speaking about the corporation, which he convincingly deems neither an experiment in democracy or solidarity nor a natural entity but an artifact, recognized and protected by the state, granted many of the same rights as persons, for the sole instrumental end of raising capital. ${ }^{119}$ And this is, in turn, consistent with the value of efficiency (or wealth maximization), the normative perspective upheld by Becker and Posner himself, ${ }^{120}$ which is, furthermore, as we have seen, the ideological matter of which economics is made of.

115 Richard A. Posner, Overcoming Law (Harvard University Press 1995) 15-16.

116 Ibid 403-404.

117 Richard Posner, The Problematics of Moral and Legal Theory (Harvard University Press 2009) 6-7.

118 J. Kiley Hamlin, 'Failed Attempts to Help and Harm: Intention Versus Outcome in Preverbal Infants' Social Evaluations' (September 2013) Cognition 128(3): 451-474 <https://doi.org/10.1016/j.cognition.2013.04.004> accessed 14 May 2017.

119 Posner, Overcoming Law, op. cit., 285-286.

120 Steven G. Medema, 'From Dismal to Dominance? Law and Economics and the Values of Imperial Science, Historically Contemplated' in Aristides 
All of the above brings us to Coase, the British-born American economist whose seminal essay 'The Problem of Social Cost' is one of the most cited articles in our field and is credited with the birth of the Coase Theorem, i.e. a centerpiece of the modern law and economics movement. ${ }^{121}$ What Coase says is that the legal system affects transaction costs and the goal of such a system is to minimize harm or costs, broadly conceived. ${ }^{122}$ From the latter it follows that in a world without transaction costs (where parties can bargain and make contracts without trouble) rights naturally flow into the hands of whoever will pay the most for them, and in the case of a legal dispute the highest bidder will be assigned rights by the law and will simply keep them, or will buy rights from whoever else they are assigned to. ${ }^{123}$ Law and economics as conceived nowadays is founded precisely on that idea, i.e. that the purpose of law is to serve as a substitute for the agreements people would reach with each other if they could, being concerned more about the cheapest solution rather than whoever has caused the problem, and this, in turn, is based on the assumption that people can bargain their way to waste-free results. Although there is ambiguity regarding what exactly transaction cost means, ${ }^{124}$ and, moreover, bargaining is not exactly easy in the real world, ${ }^{125}$ Coase recognizes such situations, and, accordingly, concludes that in such cases the authority handing out rights should aim at making a winner out of whoever values the rights more. It follows then that the Coasean view leans towards letting markets take care of bigger problems than lawsuits.

Coase's impact on law and economics as a school of thought would not be complete without considering 'The Nature of the Firm', which argues that all of a firm's production decisions are a result of comparing

Hatzis and Nicholas Mercuro (eds), Law and Economics: Philosophical Issues and Fundamental Questions (Routledge 2015) 69.

121 Steven Medema and Richard Zerbe, 'The Coase Theorem' in B Bouckaert and G De Geest (eds), Encyclopedia of Law and Economics (Edward Elgar Publishing and University of Ghent 1996-2000) 836-892.

122 Ronald Coase, 'The Problem of Social Cost' (1960) Journal of Law and Economics 3: 1-44.

123 Ward Farnsworth, The Legal Analyst: A Toolkit for Thinking about the Law (Kindle Locations 1273-1274). University of Chicago Press Kindle Edition. 124 Douglas Allen, 'Transaction Costs' in B Bouckaert and G De Geest (eds), Encyclopedia of Law and Economics (Edward Elgar Publishing and University of Ghent 1996-2000) 893-926.

125 Farnsworth, op. cit. 
the marginal value of internal production against market transactions. ${ }^{126}$ The basic premise of Coase in 'The Nature of the Firm' is that the production of goods can be done by an entrepreneur without any organization around him or her, and that whenever more complex arrangements are necessary, following traditional economic theory, the market is efficient, and therefore it should always be cheaper to contract out with other entrepreneurs rather than hiring employees; nevertheless, Coase continues, there is a cost in doing transactions in the open market (search and information, bargaining, trade secrets, policing and enforcement, etc.) so a firm is originated whenever doing things internally avoids such costs. ${ }^{127}$ It follows, then, that management merely reacts to price changes by rearranging the factors of production under its control. ${ }^{128}$ From these foundations it can be inferred that a firm is no more than a web of private contracts, as externalizing production on the market is the alternative to internalizing it within a firm, a mere method of economic organization. This gives way to the nexus of contracts or contractual theory of the firm, which, in turn, is in stark contrast to the historical legal concept of the corporation as an entity created by the state, and, henceforth, stands opposed to state intervention. ${ }^{129}$ Furthermore, another expected ramification of this view is the separation of ownership and control, a concept first popularized by Berle and Means in their famous work The Modern Corporation and Private Property. Berle and Means argue that the dispersed owners of the modern corporation, who pool their resources into a firm precisely to produce goods and services at a bigger scale compared to simply contracting in the open market, do not have the incentive to control managers, who, in turn, act in their own interests. ${ }^{130}$ This is where the view that company law is all about aligning the interests of agents and principals within a firm comes from.

Following up on the historical review of economics imperialism, the most revealing issue about Coase and his elegant theory is that they were not embraced by the mainstream until sufficiently reduced to the myth of

126 Herbert Hovenkamp, 'Neoclassicism and the Separation of Ownership and Control' (2009) Virginia Law and Business Review 4: 373; U Iowa Legal Studies Research Paper No. 08-52.

127 Ronald Coase, 'The Nature of the Firm' (2007, orig. 1937) Economica 4(16).

128 Ibid.

129 Henry Butler, 'The Contractual Theory of the Corporation' (1989) George Mason Law Review 11(4): 99-123; George Mason Law and Economics Research Paper No. 12-19.

130 Ibid. 
the optimizing individual - and Coase himself was vocal about inductivism as a better alternative to 'blackboard economics'. ${ }^{131}$ It is not hard to see what Coase himself feared. The apparent triumph of the economic analysis of law grants hegemony to a profit-maximizing view which simplistically reduces the individual to how it organizes production, distribution, and consumption, i.e. the person as a self-aggrandizing profit and preference maximizer. ${ }^{132}$ And this commodification is in sharp contrast to law, which is at the core of the process of humanizing while civilizing the human being. When Parisi quotes Coase saying that the cohesiveness of economic techniques allows economics to move into another field, such as law, and intellectually dominate it, ${ }^{133}$ it is forgotten that the approach of economics is built on testable models derived by means of logical deduction and then tested empirically, while legal analysis, at least in the Anglo-American tradition, is inductive. This clash seems to completely escape the minds of a cheerleading group of lawyers (surely anxious to belong to the esoteric circle of 'economic experts') who have even gone so far as to claim that corporate law has reached its end and is basically dead, for the primacy of the shareholder model has triumphed and the convergence of corporate governance regimes is irreversible - which means, basically, that there is no point discussing it anymore. ${ }^{134}$ In a best case scenario, this is evidently silly, and, in a worst case scenario, it is anti-intellectual and the stuff of an Orwellian thoughtcrime-like totalitarianism.

As Berle and Means acknowledge:

The rise of the modern corporation has brought a concentration of economic power which can compete on equal terms with the modern state - economic power versus political power, each strong in its own field. The state seeks in some aspects to regulate the corporation, while the corporation, steadily

131 Milonakis and Fine, op. cit., 305.

132 Jane Radin and Madhavi Sunder, 'The Subject and Object of Commodification', in Martha Ertman and Joan Williams (eds), Rethinking Commodification: Cases and Readings in Law and Culture (New York University Press 2005) <http://ssrn.com/abstract=582641> accessed 14 May 2017.

133 Francesco Parisi, 'Positive, Normative and Functional Schools in Law and Economics' (2004) European Journal of Law and Economics 1(3): 259-272; George Mason Law and Economics Research Paper No. 04-22.

134 Henry Hansmann and Reinier Kraakman, 'The End of History for Corporate Law' Yale Law School Working Paper No. 235; NYU Working Paper No. 013; Harvard Law School Discussion Paper No. 280; Yale SOM Working Paper No. ICF-00-09, January $2000<$ http://ssrn.com/abstract=204528> accessed 16 May 2017. 
becoming more powerful, makes every effort to avoid such regulation. Where its own interests are concerned, it even attempts to dominate the state. The future may see the economic organism, now typified by the corporation, not only on an equal plane with the state, but possibly even superseding it as the dominant form of social organization. ${ }^{135}$

Therefore, if not out of intellectual honesty then at least based on sheer pragmatic reasons it is urgent to recognize the highly political nature of company law, to study and debate it, for 'to make good company law is a question of how to make good society'. ${ }^{136}$ There is little or nothing of a 'value free science' in economics, from theory choice and the assumptions of economics about individual behavior to equilibria and efficiency, ${ }^{137}$ hence it is fair game to meet it in the arena of value judgments.

\section{THE REFRAMING GOALPOSTS}

Why do businesspeople transact through a firm instead of doing it in the open market? Before Ronald Coase's paper 'The Nature of the Firm', economists considered that ownership and institutions neither affected the objective of the firm nor its knowledge base, technology or cost efficiency, mostly because 'market-contracting perfectly solves all incentive and coordination issues'. ${ }^{138}$ The Coasian view is that there are high costs in contracting repeatedly in the open market and that it incentivizes unrelated parties to behave opportunistically against each other. Henceforth, the orthodoxy says that in a firm participants have less leeway to be opportunistic, enabling transacting parties to find an equilibrium since the legal entity holds the firm's assets while diversifying the risks of the shareholders and delegating control rights to management as a means of incentivizing risk taking. ${ }^{139}$ Moreover, the firm relative to the market

135 Adolf Berle and Gardiner Means, The Modern Corporation and Private Property (reprint edn, Transaction Publishers 1991) 44.

136 Jukka Mähönen, 'Do We Need Law and Economics in Company Law?'

(2009) Nordisk Tidsskrift For Selskabsret, Nr. 1/2: 146-157.

137 Medema, 'From Dismal to Dominance?', op. cit.

138 Nicolai J. Foss and Peter G. Klein, 'The Emergence of the Modern Theory of the Firm' (January 2006) Center for Strategic Management and Globalization, Copenhagen Business School, $12<$ http://ssrn.com/abstract= 982094> accessed 17 May 2017.

139 Erik Vermeulen, 'The Role of the Law in Developing Efficient Corporate Governance Frameworks' in Corporate Governance of Non-Listed Companies in Emerging Markets (OECD Publishing 2006) 96. 
provides the certainty through continuous transacting, i.e. the continuity of association among input owners. ${ }^{140}$

This particular raison d'être for firms has two dimensions, i.e. the principal-agent divide and the aspect of the incomplete contracts. The separation between ownership and control in terms of a principal on one side (investors/outsiders) and an agent on the other (manager/insider) ${ }^{141}$ triggers the issue of information asymmetries, opportunistic behavior (again!), strategic bargaining, and transaction costs vis-à-vis incomplete contracts $^{142}$ - because, after all, with perfect and costless contracting firms would be unnecessary, ${ }^{143}$ or so the theory goes. Furthermore, this view is nested in the conception that a firm is nothing other than a nexus of contracts. ${ }^{144}$ Besides bringing to the fore the debate on the economic rationale of contract regulation and claiming to be descriptive, this theoretical approach narrows down company law to the governance of corporations, i.e. looking through the lens of agency relationships among contractual parties and the related problems of agency costs among them. ${ }^{145}$

There are important implications to such a framework, not the least that it monopolizes most of the liters of ink spent on writing about corporate governance. The most notorious one is the dichotomy of shareholder primacy (contractarian view or property model) ${ }^{146}$ as opposed to stakeholder primacy (communitarian view or entity model). ${ }^{147}$ Agency theory is, actually, cemented on such a split, with its variations,

140 Foss and Klein, op. cit.

141 Jean Tirole, 'Corporate Governance' Centre for Economic Policy and Research, London. Discussion Paper No. 2086. February, 1999, 1.

142 Oliver D. Hart 'Norms and the Theory of the Firm' (May 2001 Harvard Institute of Economic Research Paper No. 1923; Harvard Law and Economics Discussion Paper No. 326. page 2) <http://ssrn.com/abstract=269234> accessed 19 May 2017.

143 Foss and Klein, op. cit.

144 Hovenkamp, op. cit.

145 Stefano Lombardo and Piero Pasotti, 'Disintegrating the Regulation of the Business Corporation as a Nexus of Contracts: Regulatory Competition vs. Unification of Law' (March 2008) European Corporate Governance Institute Law Working Paper No. 102/2008 <http://ssrn.com/abstract=1112091> accessed 21 May 2017.

146 Tirole, op. cit., 3.

147 Mähönen, op. cit. 
for example: is the key agency problem between financiers and management or between financiers, between minority shareholder and controlling shareholders, or between firm insiders and outsiders? ${ }^{148}$ This is a reflection of how the firm has impacted classical economic theory, as Berle affirms when saying that the firm shifted the management function from entrepreneurial capitalist owners into administrators. ${ }^{149}$ The way corporate governance is studied, the framing of the problem offers its own conclusions, i.e. 'the contemporary corporate governance debate is concerned primarily with the design of a legal, institutional and regulatory framework that helps protect weak and widely dispersed shareholders against self-interested managers' ${ }^{150}$ Some outliers place both managers and controlling shareholders within the classification of 'insiders' as opposed to creditors and outside investors, as in the case of $\mathrm{La}$ Porta, Lopez-de-Silanes, Shleifer and Vishny, who define corporate governance as 'a set of mechanisms through which outside investors protect themselves against expropriation by the insiders'. ${ }^{151}$

Figure 1.2 shows the skeleton of agent theory, the assumptions on which it rests, and its implications.

This is the level of analysis which, at the core, will be found in all corporate governance books, particularly those churned out in legal academia. Henceforth, it shall be the structure that we will hold against the light of other approaches in order to demonstrate that, as obvious as it may sound, there is no such thing as settled science in the realm of political philosophy.

148 Enrique Rueda-Sabaer, 'Corporate Governance: And the Bargaining Power of Developing Countries to Attract Foreign Investment' (2000) Corporate Governance: An International Review 8(2): 117-124. Blackwell Publishers Ltd. $<$ http://dx.doi.org/10.1111/1467-8683.00189> 121.

149 Adolf A. Berle, 'The Impact of the Corporation on Classical Economic Theory' in Thomas Clarke (ed.), Theories of Corporate Governance: The Philosophical Foundations of Corporate Governance (Routledge 2007) 44.

150 Vermeulen, op. cit., 92.

151 Rafael La Porta, Florencio Lopez-de-Silanes, et al., 'Investor Protection: Origins, Consequences, Reform' (October 1999 Harvard Institute for Economic Research, Harvard University. Discussion Paper Number 188) <https://ssrn.com/ abstract=183908> accessed 24 May 2017. 


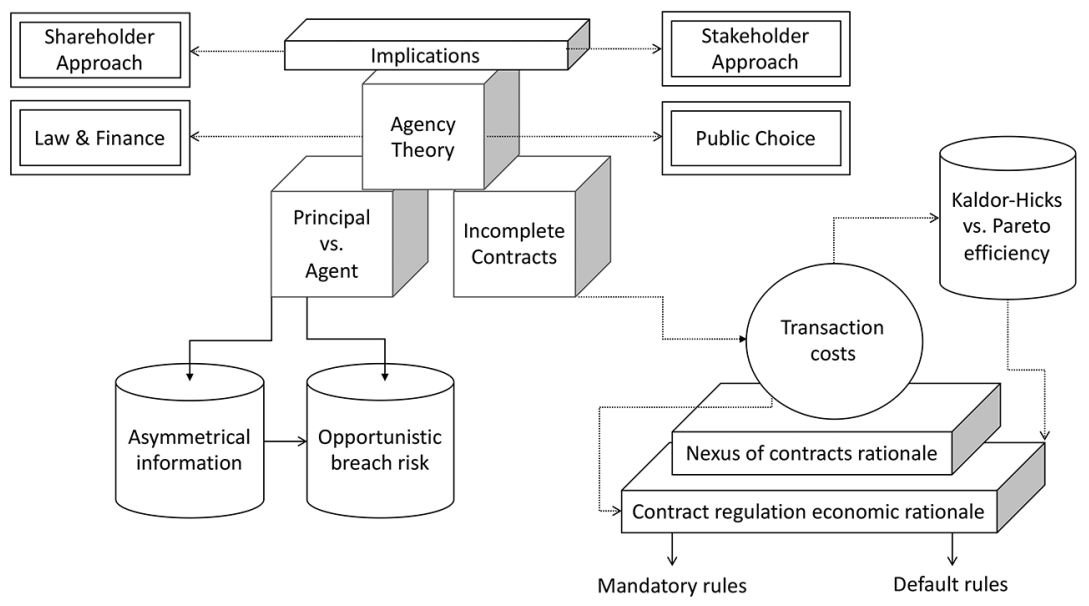

Figure 1.2 Agency theory

\section{BIBLIOGRAPHY}

\section{Books}

Allen, Douglas, 'Transaction Costs' in B. Bouckaert and G. De Geest (eds), Encyclopedia of Law and Economics (Edward Elgar Publishing and University of Ghent 1996-2000)

Arestis, Philip and Malcolm Sawyer (ed.), A Biographical Dictionary of Dissenting Economists (Edward Elgar Publishing 2000)

Ayres, Robert, Turning Point: An End to the Growth Paradigm (Earthscan 1998)

Berle, Adolf A., 'The Impact of the Corporation on Classical Economic Theory' in Thomas Clarke (ed.), Theories of Corporate Governance: The Philosophical Foundations of Corporate Governance (Routledge 2007)

Berle, Adolf and Gardiner Means, The Modern Corporation and Private Property (reprint edn, Transaction Publishers 1991)

Bitterman, H.J. 'Adam Smith's Empiricism and the Law of Nature, Parts I-II' in John Cunningham Wood (ed.), Adam Smith: Critical Assessments (Routledge 1993)

Caldwell, Bruce, Beyond Positivism (Routledge 1994)

Cannon, John, Aristocratic Century: The Peerage of Eighteenth-Century England (Cambridge University Press 1984)

Chang, Ha-Joon, Economics: A User's Guide (Penguin 2014)

Cohen, Mitchell et al. (ed.) Princeton Readings in Political Thought (Princeton University Press 1996) 
Collison Black, R.D., 'Jevons, Marshall and the Utilitarian Tradition' in Frank Ackerman et al. (eds), Human Well-Being and Economic Goals (Island Press 1997)

Deane, Phyllis, The Evolution of Economic Ideas (Cambridge University Press 1993)

Diggins, John P., Thorstein Veblen: Theorist of the Leisure Class (Princeton University Press 1999)

Fleck, Ludwik, Genesis and Development of a Scientific Fact (University of Chicago Press 1979)

Foster, Nicholas H.D., 'The Theoretical Background: The Nature of the Actors in Corporate Social Responsibility' in Stephen Tully (ed.), Research Handbook in Corporate Legal Responsibility (Edward Elgar Publishing 2005)

Friedman, Milton, 'The Methodology of Positive Economics' in Essays in Positive Economics (University of Chicago Press 1966)

Gauch, Hugh G., Scientific Method in Practice (Cambridge University Press 2003)

Gottheil, Fred M., Principles of Economics (Cengage Learning 2012)

Graeber, David, Debt: The First 5,000 Years (Melville House 2012)

Griswold Jr., Charles L., Adam Smith and the Virtues of Enlightenment (Cambridge University Press 1999)

Hankins, Thomas L., Science and the Enlightenment (Cambridge University Press 1985)

Harford, Tim, The Logic of Life (Abacus 2009)

Hausman, Daniel, The Inexact and Separate Science of Economics (Cambridge University Press 1992)

Hayek, Friedrich, Individualism and Economic Order (University of Chicago Press 1958)

Hodgson, Geoffrey M., The Evolution of Institutional Economics: Agency, Structure and Darwinism in American Institutionalism (Routledge 2004)

Hont, I. and Ignatieff, M., Wealth and Virtue: The Shaping of Political Economy in the Scottish Enlightenment (Cambridge University Press 1983)

Kahneman, Daniel, Thinking, Fast and Slow (Penguin, 2011)

Keen, Steve, Debunking Economics: The Naked Emperor Dethroned? (Zed Books 2011)

Kuhn, Thomas S., 'The Structure of Scientific Revolutions' (University of Chicago Press 2012)

Lipsey, Richard and Harbury, Colin, First Principles of Economics (2nd edn, Oxford University Press 2004)

Maas, Harro, William Stanley Jevons and the Making of Modern Economics (Cambridge University Press 2005)

MacKaay, Ejan, 'History of Law and Economics' in B Bouckaert and G De Geest (eds), Encyclopedia of Law and Economics (Edward Elgar Publishing and University of Ghent 1996-2000)

Mackie, Christopher, Canonizing Economic Theory: How Theories and Ideas are Selected in Economics (Routledge 2015)

Mankiw, Gregory, Principles of Economics (South-Western 2012)

Marshall, Alfred, Principles of Economics (unabridged 8th edn, Cosimo 2009) 
Medema, Steven and Richard Zerbe, 'The Coase Theorem' in B. Bouckaert and G. De Geest (eds), Encyclopedia of Law and Economics (Edward Elgar Publishing and University of Ghent 1996-2000)

Medema, Steven G., 'From Dismal to Dominance? Law and Economics and the Values of Imperial Science, Historically Contemplated' in Aristides Hatzis and Nicholas Mercuro (eds), Law and Economics: Philosophical Issues and Fundamental Questions (Routledge 2015)

Medina, Roberto, Principles of Economics (Rex 2003)

Menger, Carl, Investigations into the Method of the Social Sciences with Special Reference to Economics (Mises Institute 2009)

Menger, Carl, The Origins of Money (Ludwig von Mises Institute 2009)

Mill, John Stuart, Principles of Political Economy with Some of their Applications to Social Philosophy (London 1871)

Milonakis, D. and B. Fine, From Political Economy to Economics: Method, the Social and the Historical in the Evolution of Economic Theory (Routledge 2009)

Milton, John, Paradise Lost [Kastan edition] (first published 1667, Hackett 2005)

Muthu, Sankar, Enlightenment against Empire (Princeton University Press 2003)

Polanyi, Karl, The Great Transformation: The Political and Economic Origins of Our Time (Beacon Press 2002)

Posner, Richard A., Overcoming Law (Harvard University Press 1995)

Posner, Richard A., Frontiers of Legal Theory (Harvard University Press 2004)

Posner, Richard A., The Problematics of Moral and Legal Theory (Harvard University Press 2009)

Radin, Jane and Sunder, Madhavi, 'The Subject and Object of Commodification', in Martha Ertman and Joan Williams (eds), Rethinking Commodification: Cases and Readings in Law and Culture (New York University Press 2005)

Rist, Gilbert, The Delusion of Economics: The Misguided Certainties of a Hazardous Science (Zed Books 2001)

Rosen, Michael, 'The Marxist Critique of Morality and the Theory of Ideology' in Edward Harcourt (ed.), Morality, Reflection and Ideology (Oxford University Press 2000) 21-43

Samuels, Warren, The Founding of Institutional Economics (Routledge 1998)

Samuelson, Paul, Economics (19th edn, McGraw-Hill 2000)

Schumpeter, Joseph A., History of Economic Analysis (Routledge 1997)

Shaw, William H., Marx's Theory of History (Stanford University Press 1978)

Sloth Andersen, Esben, Schumpeter's Evolutionary Economics: A Theoretical, Historical and Statistical Analysis of the Engine of Capitalism (Anthem 2009)

Veblen, Thorstein, The Theory of Business Enterprise (Blackmask 1999)

Vermeulen, Erik, 'The Role of the Law in Developing Efficient Corporate Governance Frameworks' in Corporate Governance of Non-Listed Companies in Emerging Markets (OECD Publishing 2006)

Vickers, Douglas, Economics and Ethics: An Introduction to Theory, Institutions and Policy (Praeger 1997)

von Mises, Ludwig, Human Action: A Treatise in Economics (The Scholar's edn, Ludwig von Mises Institute 1998)

von Wieser, Friedrich, Social Economics (Greenberg 1927)

Walras, Léon, Elements of Pure Economics (Routledge 2003) 
Weber, Max, Economy and Society: An Outline of Interpretive Sociology (University of California Press 1978)

\section{Papers}

Adami, Christoph and Arend Hintze, 'Evolutionary Instability of Zerodeterminant Strategies Demonstrates that Winning is Not Everything' (2011) Nature Communications 4, Nature Publishing Group <http://dx.doi.org/10. 1038/ncomms3193> accessed 8 May 2017

Brian, Arthur W., 'Inductive Reasoning and Bounded Rationality' (1994) The American Economic Review 84(2): 406-411

Bristow, William, 'Enlightenment' in Edward N. Zalta (ed.), The Stanford Encyclopedia of Philosophy (2011) https://plato.stanford.edu/archives/sum 2011/entries/enlightenment/> accessed 17 April 2017

Butler, Henry, 'The Contractual Theory of the Corporation' (1989) George Mason Law Review 11(4): 99-123; George Mason Law and Economics Research Paper No. 12-19.

Cat, Jordi, 'The Unity of Science' in Edward N. Zalta (ed.), The Stanford Encyclopedia of Philosophy (2017) <https://plato.stanford.edu/archives/spr 2017/entries/scientific-unity/> accessed 1 May 2017

Cliffe Leslie, T.E., 'The Political Economy of Adam Smith' Fortnightly Review, 1 November $1870<$ http://socserv.mcmaster.ca/econ/ugcm/3113/leslie/leslie01. html $>$ accessed 21 April 2017

Coase, Ronald, 'The Nature of the Firm' (2007, orig. 1937) Economica 4(16)

Coase, Ronald, 'The Problem of Social Cost' (1960) Journal of Law and Economics 3: 1-44

Deane, Phyllis, 'The Scope and Method of Economic Science' (1983) The Economic Journal 93(369): 1-12

Foss, Nicolai J. and Peter G. Klein, 'The Emergence of the Modern Theory of the Firm' (January 2006) Center for Strategic Management and Globalization, Copenhagen Business School, p. 12 <http://ssrn.com/abstract=982094> accessed 17 May 2017

Green, Leslie, 'Law as a Means' HART-FULLER AT 50, Peter Cane, ed., Oxford: Hart Publishing; Oxford Legal Studies Research Paper No. 8/2009 $<$ http://ssrn.com/abstract=1351304> accessed 13 May 2017

Hamlin, J. Kiley, 'Failed Attempts to Help and Harm: Intention Versus Outcome in Preverbal Infants' Social Evaluations' (2013) Cognition 128(3): 451-474 $<$ https://doi.org/10.1016/j.cognition.2013.04.004> accessed 14 May 2017

Hansmann, Henry and Reinier Kraakman, 'The End of History for Corporate Law' (2000) Yale Law School Working Paper No. 235; NYU Working Paper No. 013; Harvard Law School Discussion Paper No. 280; Yale SOM Working Paper No. ICF-00-09, January $2000<$ http://ssrn.com/abstract=204528> accessed 16 May 2017

Hart, Oliver D., 'Norms and the Theory of the Firm' (May 2001) Harvard Institute of Economic Research Paper No. 1923; Harvard Law and Economics Discussion Paper No. 326, p. 2 <http://ssrn.com/abstract=269234> accessed 19 May 2017 
Häuser, Karl, 'Historical School and "Methodenstreit"” (1988) Journal of Institutional and Theoretical Economics 144(3): 532-542

Heath, Joseph, 'Methodological Individualism' in The Stanford Encyclopedia of Philosophy (2011) <http://plato.stanford.edu/archives/spr2011/entries/ methodological-individualism/> accessed 6 May 2017

Henrich, Joseph, Robert Boyd, et al., 'In Search of Homo Economics: Behavioral Experiments in Fifteen Small-Scale Societies' (May 2011) The American Economic Review 91(2): 73-78

Hollinger, David A., 'The Accommodation of Protestant Christianity with the Enlightenment: An Old Drama Still Being Enacted' [Winter 2012] Dædalus, the Journal of the American Academy of Arts and Sciences 141(1): 11

Hovenkamp, Herbert, 'Neoclassicism and the Separation of Ownership and Control' (2009) Virginia Law and Business Review 4: 373; U Iowa Legal Studies Research Paper No. 08-52

Humphrey, Caroline, 'Barter and Economic Disintegration' (Mar., 1985) Man, New Series, 20(1): 48-72

Jay Epstein, Edward, 'Warren Buffet's Hidden Stake in Financial Weapons of Mass Destruction' (February 2009) Vanity Fair <http://www.vanityfair. com/news/2009/02/warren-buffetts-hidden-stake-in-financial-weapons-of-massdestruction> accessed 6 May 2017

Kahneman, Daniel 'Biographical' (Nobel Media, 2014) <http://www.nobel prize.org/nobel_prizes/economic-sciences/laureates/2002/kahneman-bio.html> accessed 11 July 2017

Kahneman, Daniel and Amos Tversky, 'Prospect Theory: An Analysis of Decision Under Risk' (1979) Econometrica 47(2): 263

Kornhauser, Lewis, 'The Economic Analysis of Law' in Edward N. Zalta (ed.), The Stanford Encyclopedia of Philosophy (Fall 2011 Edition) <http://plato. stanford.edu/archives/fall2011/entries/legal-econanalysis/> accessed 3 November 2012

Kubiszewski, Ida, 'Beyond GDP: Measuring and Achieving Global Genuine Progress' (April 2013) Ecological Economics 93: 57-68<http://www. elsevier.com/locate/ecolecon> accessed 2 May 2017

La Porta, Rafael, Florencio Lopez-de-Silanes, et al., 'Investor Protection: Origins, Consequences, Reforms' (October 1999) Harvard Institute for Economic Research, Harvard University. Discussion Paper Number $188<$ https://ssrn. com/abstract=183908> accessed 24 May 2017

Lombardo, Stefano and Piero Pasotti, 'Disintegrating the Regulation of the Business Corporation as a Nexus of Contracts: Regulatory Competition vs. Unification of Law' (March 2008) European Corporate Governance Institute Law Working Paper No. 102/2008 <http://ssrn.com/abstract=1112091> accessed 21 May 2017

Louzek, Marek, 'The Battle of Methods in Economics. The Classical Methodenstreit - Menger vs. Schmoller' (2011) American Journal of Economics and Sociology 70: 439-463

Mähönen, Jukka, 'Do We Need Law and Economics in Company Law?' (2009) Nordisk Tidsskrift For Selskabsret, Nr. 1/2: 146-157 
Parisi, Francesco, 'Positive, Normative and Functional Schools in Law and Economics' (2004) European Journal of Law and Economics 1(3): 259-272; George Mason Law and Economics Research Paper No. 04-22

Rodrigo, G. Chris, 'Micro and Macro: The Economic Divide' (2012) International Monetary Fund, Finance and Development, 31 January <http://www. imf.org/external/pubs/ft/fandd/basics/bigsmall.htm> accessed 6 May 2017

Rueda-Sabaer, Enrique, 'Corporate Governance: And the Bargaining Power of Developing Countries to Attract Foreign Investment' (2000) Corporate Governance: An International Review 8(2): 117-124. Blackwell Publishers Ltd. $<\mathrm{http}: / / \mathrm{dx}$. doi.org/10.1111/1467-8683.00189>

Saiman, Chaim N., 'Jesus' Legal Theory - A Rabbinic Interpretation' Villanova Law/Public Policy Research Paper No. 2007-15; (2007-2008) Journal of Law and Religion, 23: $97<$ http://ssrn.com/abstract=992280> accessed 10 May 2017

Tamahana, Brian Z., 'How an Instrumental View of Law Corrodes the Rule of Law' (2007) DePaul Law Review 56; St. John's Legal Studies Research Paper No. 06-0061 <http://ssrn.com/abstract=951518> accessed 11 May 2017

Tamahana, Brian Z., 'The Dark Side of the Relationship between the Rule of Law and Liberalism' St. John's Legal Studies Research Paper No. 08-0096 $<$ http://ssrn.com/abstract=1087023> accessed 9 May 2017

'Tap Dancing: The New Republic Online Debate between Richard A. Posner and Philip B. Heyman' (01.31.2006), available on the Harvard Law School International Center for Criminal Justice website <http://www.law.harvard.edu/ programs/criminal-justice/posner-heymann-debate.pdf> accessed 11 May 2017

Thaler, Richard, 'Toward a Positive Theory of Consumer Choice' (1980) Journal of Economic Behavior and Organization 39-60

Tirole, Jean, 'Corporate Governance' Centre for Economic Policy and Research, London. Discussion Paper No. 2086. February, 1999, 1

\section{Electronic Sources}

Farnsworth, Ward, The Legal Analyst: A Toolkit for Thinking about the Law (Kindle Locations 1273-1274). University of Chicago Press Kindle Edition

Freakonomics Radio, 'The Men Who Started a Thinking Revolution' (4 January 2017) 3:47-3:55, comments by Stephen J. Dubner, podcast host <http:// freakonomics.com/podcast/men-started-thinking-revolution/> accessed 11 July 2017 